Abstracta Iranica Abstracta Iranica

Revue bibliographique pour le domaine irano-aryen

Volume 29 | 2008

Comptes rendus des publications de 2006

\title{
Les Orients de Pierre Loti par la photographie. Paris, Monum - Éditions du patrimoine, 2006, 252 p.
}

Jean-Pierre Digard

\section{(2) OpenEdition}

1 Journals

Édition électronique

URL : http://journals.openedition.org/abstractairanica/29562

DOI : 10.4000/abstractairanica.29562

ISSN : 1961-960X

Éditeur :

CNRS (UMR 7528 Mondes iraniens et indiens), Éditions de l'IFRI

Édition imprimée

Date de publication : 15 mai 2008

ISSN : 0240-8910

Référence électronique

Jean-Pierre Digard, « Les Orients de Pierre Loti par la photographie. Paris, Monum - Éditions du patrimoine, 2006, 252 p. », Abstracta Iranica [En ligne], Volume 29 | 2008, document 253, mis en ligne le 15 septembre 2008, consulté le 26 septembre 2020. URL : http://journals.openedition.org/ abstractairanica/29562 ; DOI : https://doi.org/10.4000/abstractairanica.29562

Ce document a été généré automatiquement le 26 septembre 2020.

Tous droits réservés 


\title{
Les Orients de Pierre Loti par la photographie. Paris, Monum - Éditions du patrimoine, 2006, 252 p.
}

\author{
Jean-Pierre Digard
}

1 Évocation des voyages en Orient de Pierre Loti illustrée par ses propres photographies. Les pages consacrées à la Perse ne sont pas les plus nombreuses (pp. 136-139, 176-189) mais pas non plus les moins intéressantes. Venant de l'Inde, Pierre Loti aborde les rivages iraniens du golfe Persique le 7 avril 1900, chargé d'une vague mission géographique dont ne font état, ni son journal, ni son livre Vers Ispahan paru en 1904. Se trouver dans " la ville bleue " (Eșfahān) pour la saison des roses est son but principal. Ses exclamations admiratives - « Tout ce que l'on voit est idéalement oriental » (p. 136) - et son sentiment, pour lui toujours positif, « d'être revenu en arrière, dans le recul des âges » (p. 137), suffisent à donner une idée de la distance qui sépare la Perse d'hier de l'Iran d'aujourd'hui. Toujours chevauchant de nuit, pour échapper à la fournaise du jour, il rencontre surtout ruines, squelettes d'animaux morts au désert, vents chargés de poussière... Via Šīrāz, Eșfahān, Kāšān et Qom, il arrive à Téhéran, ville (déjà) laide, dont il n'attendait rien, et où il ne trouve guère à noter qu'« un chat, un vrai » sur le trône du chah...

2 On ne peut s'empêcher d'être gagné par la nostalgie, à la contemplation de ces photographies vieillies de monuments à la somptuosité poussiéreuse, de villes et de villages en ruines - constante de l'« urbanisme " persan ancien - et de scènes d'une vie quotidienne irrémédiablement disparue. «Beauté, décadence, les deux grands thèmes de l'œuvre de Loti » (p. 139). 
INDEX

Thèmes : 5.1. Monde iranophone

\section{AUTEURS}

JEAN-PIERRE DIGARD

CNRS - Mondes iranien et indien - Paris 